\title{
Kajian Awal Penerapan Anodizing Technique pada Keramik Berpori dari Lempung (Clay)
}

Sari Wantia, Asifa Asria, Mariana B. Malino ${ }^{\text {a* }}$

aProdi Fisika, FMIPA Universitas Tanjungpura

Jalan Prof. Dr. Hadari Nawawi, Pontianak, Indonesia

*Email : marianamalino9@gmail.com

\begin{abstract}
Abstrak
Penelitian yang telah dilakukan bertujuan untuk membuat keramik berpori berbasis lempung dan meningkatkan persentase pori keramik menggunakan anodizing technique. Proses pembuatan keramik berpori dilakukan secara manual melalui lima tahapan yaitu penghalusan lempung, pencampuran bahan pembentuk keramik, pencetakan dengan bentuk setengah bola berongga, pengeringan dan sintering pada suhu $945^{\circ} \mathrm{C}$. Hasil penelitian menunjukkan nilai susut massa dan susut volume tertinggi setelah fabrikasi berturut-turut sebesar $14,41 \%$ dan 33,95\%. Proses anodizing technique menggunakan larutan elektrolit $\mathrm{HCl}$ 0,2 M dengan rapat arus $25 \mathrm{~mA} / \mathrm{cm}^{2}$ dan variasi waktu anodizing yaitu 10, 15, 20, 25 dan 30 menit. Porositas tertinggi diperoleh dari sampel dengan waktu anodizing 30 menit sebesar 49,34\%. Namun sampel yang diberi perlakuan anodizing selama 30 menit mengalami penurunan nilai laju alir sekitar 59\% dibandingkan sampel tanpa perlakuan anodizing. Hal tersebut diduga disebabkan oleh pembentukan lapisan alumina oksida saat proses anodizing. Nilai laju alir tertinggi justru diperoleh sampel dengan variasi waktu anodizing 10 menit. Berdasarkan hasil uji yang diperoleh, porositas dan laju alir dipengaruhi oleh waktu anodizing. Porositas cenderung meningkat dan laju alir keramik berpori cenderung menurun seiring pertambahan waktu anodizing.
\end{abstract}

Kata Kunci: Keramik berpori, lempung (clay), anodizing, porositas, laju alir

\section{Latar Belakang}

Lempung pada dasarnya memiliki pori alami dan perlakuan pilarisasi menyebabkan pori baru timbul dengan ukuran mikropori 7,8 A [1]. Penelitian tersebut menunjukkan bahwa struktur mikro lempung dapat dimodifikasi untuk meningkatkan volume pori. Volume pori dan porositas merupakan parameter yang menunjukkan ukuran jumlah pori [1].

Analisis porositas dan laju alir untuk keramik berpori berbasis lempung sebelumnya telah dilakukan. Nilai porositas yang dihasilkan tergolong tinggi yaitu sebesar $45,36 \%$, tetapi nilai laju alir masih tergolong rendah yaitu sebesar $0,001 \mathrm{~mL} /$ menit [2]. Hal tersebut diduga disebabkan oleh susunan pori-pori yang masih bersifat tidak teratur dan tertutup sehingga menghambat aliran air.

Salah satu metode yang sudah diterapkan untuk memodifikasi struktur pori logam dan alloy adalah metode anodizing. Anodizing sudah terbukti dapat menghasilkan keteraturan pori. Membran anodik alumina berpori menghasilkan struktur pori baru dan pori yang sangat teratur setelah melalui dua tahapan anodizing dalam sistem $\mathrm{H}_{2} \mathrm{SO}_{4}-\mathrm{Al}_{2}\left(\mathrm{SO}_{4}\right)_{3}-\mathrm{H}_{2} \mathrm{O}$ pada tegangan 40 dan $50 \mathrm{~V}$ [3]. Alumina nanopori dengan interval jejari dari 130 sampai $980 \mathrm{~nm}$ dapat dihasilkan melalui proses anodizing menggunakan larutan elektrolit asam pada $50 \mathrm{~V}$ [2]. Selain itu, generasi pori yang teratur dapat diperoleh dengan menyesuaikan tingkat keasaman, kuat arus dan suhu elektrolit.

Berdasarkan uraian yang telah dipaparkan maka penelitian yang dilakukan menggunakan teknik anodizing untuk memodifikasi pori pada keramik berbahan dasar lempung. Teknik anodizing belum pernah diterapkan untuk lempung, namun dengan kandungan silika $\left(\mathrm{SiO}_{2}\right)$ dan alumina $\left(\mathrm{Al}_{2} \mathrm{O}_{3}\right)$ yang relatif tinggi masing-masing sebesar $61,43 \%$ dan $18,99 \%$ di dalam lempung [4], maka teknik anodizing memungkinkan untuk diterapkan pada lempung.

Faktor-faktor yang berpengaruh pada proses anodizing ialah kerapatan arus, kesesuaian konsentrasi elektrolit dan lama waktu anodizing [5]. Semakin lama proses anodizing menyebabkan jumlah pori bertambah semakin banyak dan ukuran pori-pori semakin besar [6]. Oleh karena itu, penelitian yang dilakukan memvariasikan lama waktu anodizing untuk menganalisis pengaruh lama waktu anodizing terhadap keteraturan pori. Target keteraturan pori yang tinggi diharapkan dapat meningkatkan laju alir air.

\section{Metodologi}

Alat-alat yang digunakan pada penelitian adalah elektroda katoda dan anoda yang berupa platina dan sampel, botol via ukuran $100 \mathrm{ml}$, bola plastik berdiameter $6,4 \mathrm{~cm}$, multimeter, neraca digital, potensio meter, ayakan 40 mesh, 
regulator tegangan, wadah anodizing, beaker glass $250 \mathrm{ml}$, mortar, kertas lakmus, wadah plastik dan tanur Carbolite bersuhu maksimum $1100^{\circ} \mathrm{C}$.

\section{Pembuatan Keramik}

Cara dan proses pembuatan keramik dilaksanakan dengan mengacu pada penelitian sebelumnya [2). Preparasi bahan baku dimulai dengaan pemotongan bongkah lempung berbentuk dadu dan menghaluskan lempung menggunakan mortar hingga berbentuk serbuk dan lolos ayak 40 mesh. Penakaran bahan serbuk lempung dan air yaitu sebanyak 66,16 gram dan air $30 \mathrm{ml}$. Proses pencampuran dilakukan selama 15 menit untuk proses pembentukan sampel.

Campuran yang telah dicampur dibentuk setengah bola secara manual menggunakan cetakan bola plastik yang berdiameter dalam 6,7 $\mathrm{cm}$ dan tebal keramik yang dibuat yaitu $0,4 \mathrm{~cm}$. Setelah sampel selesai dibentuk, sampel yang sudah agak mengeras dikeluarkan dari cetakan bola secara perlahan dan dikeringkan di bawah sinar matahari selama 5 hari. Proses pembakaran menggunakan tanur dengan pemanasan awal sampel hingga mencapai suhu $120^{\circ} \mathrm{C}$ dengan rentang $2^{\circ} \mathrm{C} /$ menit. Keramik dibakar selama 3 jam dengan rentang $5^{\circ} \mathrm{C} /$ menit untuk mencapai suhu $945^{\circ} \mathrm{C}$ untuk kemudian dilakukan holding time (penahanan) selama 2 jam. Pendinginan dilakukan secara perlahan-lahan, dengan membiarkan sampel tetap di dalam furnace selama 12 jam. Keramik hasil pembakaran pada gambar 1.

\section{Mekanisme Anodizing}

Variabel yang digunakan dalam penelitian adalah lama waktu yaitu 10, 15, 20, 25 dan 30 menit. Proses anodizing dilakukan dengan menghubungkan sampel (anoda) dan katoda (Pt) berupa platina yang tercelup sebagian dalam larutan elektrolit dengan sumber tegangan. Larutan elektrolit yang digunakan adalah $\mathrm{HCl} \mathrm{0,2}$ M. Tegangan yang digunakan sebesar $20 \mathrm{~V}$ dak kerapatan arus $25 \mathrm{~mA} / \mathrm{cm}^{2}$. Mekanisme proses anodizing pada gambar 2 .

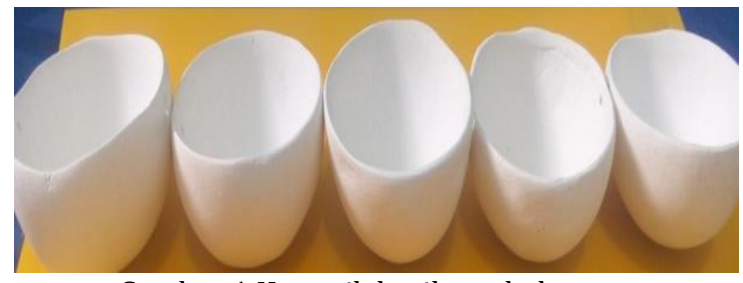

Gambar 1 Keramik hasil pembakaran

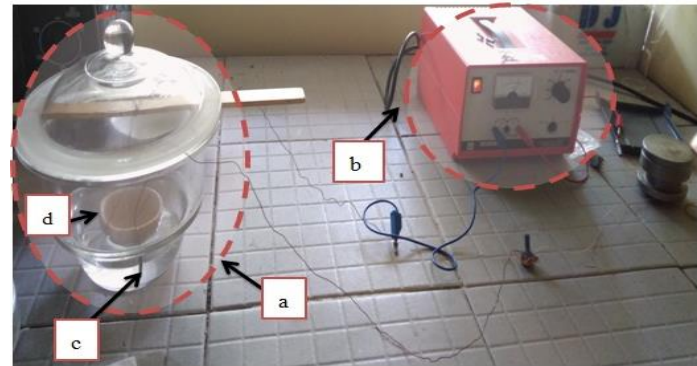

Gambar 2 Rangkaian anodizing: (a) wadah anodizing, (b) sumber tegangan power supply, (c) katoda (platina), (d) anoda (sampel)

\section{Karakterisasi Sampel}

Bahan baku berupa lempung yang digunakan dalam proses fabrikasi di analisis menggunakan XRF (X-Ray Fluoroscence) untuk melihat senyawa penyusun lempung.

Karakterisasi yang dilakukan pada sampel keramik meliputi susut bakar (susut massa dan susut volume), porositas sebelum dan setelah anodizing, laju alir air sebelum dan setelah anodizing.

Susut massa ditentukan menggunakan persamaan (1).

$$
\% \text { susut massa }=\frac{m_{0}-m_{1}}{m_{0}} \times 100 \%
$$

dengan $m_{0}$ adalah massa sebelum dibakar (gram), $m_{1}$ adalah massa sesudah dibakar (gram).

Susut bakar ditentukan menggunakan Persamaan (2).

$$
\% \text { susut volume }=\frac{V_{0}-V_{1}}{V_{0}} \times 100 \%
$$

dengan Persamaan volume setengah selimut bola:

$$
V_{1 / 2}=\frac{1}{2} x \frac{4}{3}\left(r \cdot \text { luar }^{3}-r . \text { dalam }^{3}\right)
$$

\section{(2.4)}

dengan $V_{0}$ adalah volume sebelum dibakar $\left(\mathrm{cm}^{3}\right)$, $V_{1}$ adalah volume sesudah dibakar $\left(\mathrm{cm}^{3}\right) r$ adalah jari-jari (luar dan dalam) keramik (cm).

Porositas ditentukan menggunakan Persamaan (4).

$$
p=\left(\frac{B-a}{B-c}\right) 100 \%
$$

dengan $p$ adalah porositas (\%), $B$ adalah massa basah (gram), $a$ adalah massa kering (gram), dan $c$ adalah massa gantung (gram).

Laju alir ditentukan menggunakan Persamaan (5).

$$
Q=\frac{V}{t}
$$


dengan $Q$ adalah laju alir air (mL/menit), $V$ adalah volume air (mL), $t$ adalah waktu filtrasi (menit).

\section{Hasil dan Pembahasan}

Hasil analisis bahan baku lempung menggunakan XRF diperlihatkan pada Tabel 1 . Senyawa yang dominan terdapat dalam lempung adalah silika $\left(\mathrm{SiO}_{2}\right)$ dan alumina $\left(\mathrm{Al}_{2} \mathrm{O}_{3}\right)$. Kandungan silika dan alumina yang tinggi di dalam lempung menjadi dasar bagi penggunaan anodizing technique untuk memodifikasi keramik dari lempung.

Tabel 1. Komposisi kimia lempung (clay)

\begin{tabular}{lc}
\hline & Komposisi Berat $(\%)$ \\
\cline { 2 - 2 } & Lempung (Clay) \\
\hline $\mathrm{Al}_{2} \mathrm{O}_{3}$ & 31,6 \\
$\mathrm{SiO}_{2}$ & 53,2 \\
$\mathrm{P}_{2} \mathrm{O}_{5}$ & 0,77 \\
$\mathrm{~K}_{2} \mathrm{O}$ & 2,58 \\
$\mathrm{CaO}$ & 0,55 \\
$\mathrm{TiO}_{2}$ & 5,59 \\
$\mathrm{~V}_{2} \mathrm{O}_{5}$ & 0,14 \\
$\mathrm{Cr}_{2} \mathrm{O}_{3}$ & 0,06 \\
$\mathrm{MnO}$ & 0,057 \\
$\mathrm{Fe} \mathrm{O}_{3}$ & 5 \\
$\mathrm{NiO}$ & 0,11 \\
$\mathrm{CuO}$ & 0,076 \\
$\mathrm{ZnO}$ & 0,047 \\
$\mathrm{ZrO}$ & 0,72 \\
\hline
\end{tabular}

Sumber: Ridayani [2]

\section{Analisis Susut Bakar}

Tujuan dilakukan uji susut bakar adalah melihat pengaruh pembakaran terhadap perubahan massa dan dimensi keramik. Pengukuran penyusutan massa dan volume sampel keramik dilakukan setelah sampel melalui proses pembakaran. Hasil pengukuran nilai penyusutan disajikan pada Tabel 2 .

Tabel 2 menunjukkan bahwa ada nilai penyusutan yang berbeda pada setiap sampel keramik setelah pembakaran, baik pada nilai persentase susut massa maupun pada nilai susut volume. Namun perbedaan susut massa dan susut volume tiap sampel tidak signifikan sehingga kondisi awal semua sampel dianggap homogen.

Tabel 2. Susut bakar keramik setelah pembakaran

\begin{tabular}{ccc}
\hline \multirow{2}{*}{ Sampel } & \multicolumn{2}{c}{ Susut Bakar (\%) } \\
\cline { 2 - 3 } & Susut Massa & Susut Volume \\
\hline 1 & 14,4 & 32,4 \\
2 & 14,2 & 33,1 \\
3 & 14,4 & 33,8 \\
4 & 14,0 & 33,8 \\
5 & 14,4 & 33,9 \\
\hline
\end{tabular}

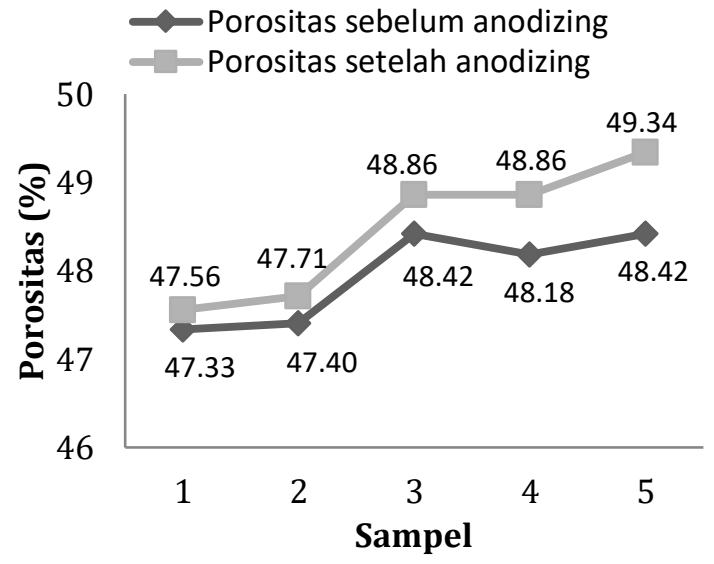

Gambar 3 Grafik Pembanding hasil porositas tanpa anodizing dan diberi perlakuan anodizing

Tahap penyusutan terjadi selama proses sintering. Penyusutan massa merupakan hasil dari proses oksidasi material organik dalam badan keramik. Selain itu, penyusutan volume dipengaruhi oleh pemampatan (densifikasi) butiran keramik setelah sisa kandungan air dikeluarkan dari dalam badan keramik [7].

\section{Analisis Porositas}

Teknik anodizing pada penelitian dilakukan untuk mengatur pori dalam konteks penyeragaman diameter pori dan geometri pori pada keramik. Dengan pori yang teratur diharapkan nilai porositas dan laju alir meningkat.

Porositas yang dituju mengacu pada jumlah volume ruang kosong yang direpresentasikan sebagai jumlah massa atau volume air yang terserap pada material keramik. Hasil perhitungan porositas sampel keramik tanpa perlakuan anodizing dan yang diberi perlakuan anodizing dapat dilihat pada Gambar 3 .

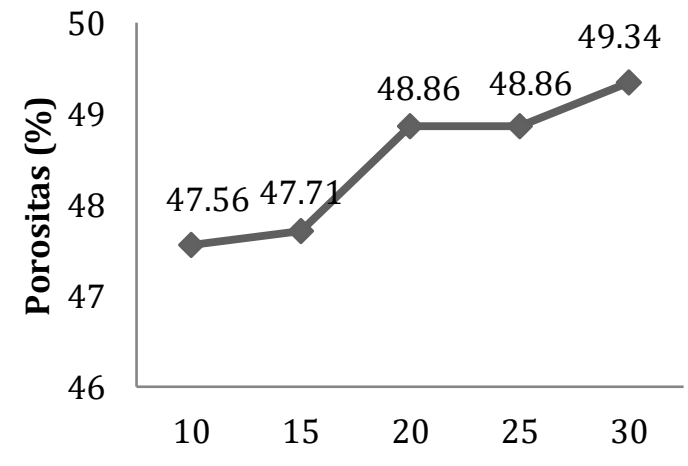

Waktu Anodizing (m)

Gambar 4 Grafik hasil persentase porositas anodizing terhadap waktu 
Tabel 3. Laju alir keramik tanpa anodizing

\begin{tabular}{|c|c|c|c|c|c|c|c|}
\hline \multirow[b]{2}{*}{ Sampel } & \multicolumn{6}{|c|}{ Volume (mL) setelah } & \multirow{2}{*}{$\begin{array}{c}\text { Jumlah Laju } \\
\text { Alir } \\
\text { (mL/jam) }\end{array}$} \\
\hline & $\begin{array}{c}0,9 \\
\text { (jam) }\end{array}$ & $\begin{array}{c}1.7 \\
\text { (jam) }\end{array}$ & $\begin{array}{c}2,5 \\
\text { (jam) }\end{array}$ & $\begin{array}{c}3,3 \\
\text { (jam) }\end{array}$ & $\begin{array}{c}4,2 \\
\text { (jam) }\end{array}$ & $\begin{array}{c}5 \\
\text { (jam) }\end{array}$ & \\
\hline 1 & 0 & 0 & 0 & 0 & 0,18 & 0,2 & 0,076 \\
\hline 2 & 0 & 0 & 0 & 0 & 0,19 & 0,19 & 0,076 \\
\hline 3 & 0 & 0 & 0 & 0 & 0,18 & 0,19 & 0,074 \\
\hline 4 & 0 & 0 & 0 & 0 & 0,17 & 0,2 & 0,074 \\
\hline 5 & 0 & 0 & 0 & 0 & 0,17 & 0,2 & 0,074 \\
\hline
\end{tabular}

Peningkatan porositas sampel setelah anodizing mengindikasikan bahwa ada perubahan yang terjadi pada pori keramik akibat oksidasi ion-ion $\mathrm{H}^{+}$terhadap senyawa-senyawa yang terkandung dalam keramik seperti $\mathrm{SiO}_{2}$ dan $\mathrm{Al}_{2} \mathrm{O}_{3}$. Peningkatan porositas seiring pertambahan waktu proses anodizing menunjukkan bahwa semakin lama waktu proses anodizing, makin banyak jumlah ion $\mathrm{H}^{+}$untuk mengoksidasi senyawa-senyawa dalam keramik.

\section{Analisis Laju Alir}

Pengujian laju alir bertujuan untuk mengetahui kemampuan sampel keramik dalam meloloskan partikel air pada rentang waktu tertentu. Volume yang dihasilkan selama rentang waktu uji alir tanpa perlakuan anodizing dapat dilihat pada Tabel 3.

Data volume yang dihasilkan selama rentang waktu uji alir setelah dilakukan perlakuan anodizing dapat dilihat pada Tabel 4 . Secara umum laju alir mengalami penurunan seiring bertambah waktu anodizing. Ilustrasi proses yang terjadi saat dilakukan anodizing diperlihatkan pada Gambar 5. Ilustrasi gambar tersebut untuk mewakili secara mikrokopis yang tidak dilakukan dalam penelitian. Gambar 5 (a) adalah keadaan pori di dalam keramik sebelum dilakukan anodizing. Terlihat bahwa pori-pori yang terbentuk tidak teratur dalam arti masih ada diameter pori dan geometri pori yang tidak seragam. Ketidakteraturan pori dilihat pada data porositas/laju alir sebelum anodizing pada Gambar 3 dan Tabel 3. Kemudian setelah dilakukan anodizing terjadi pertumbuhan pori, pori mulai terbentuk dan teratur yang ditandai dengan penyeragaman diameter pori dan geometri pori. Keteraturan pori dilihat pada data porositas setelah anodizing pada Gambar 3 dan Gambar 4. Keteraturan pori yang dimaksud seperti yang terlihat pada Gambar 5 (b). Seiring pertumbuhan pori, muncul lapisan penghalang di sekitar permukaan pori yang disebut lapisan oksida alumina yang menghalangi air untuk turun (Gambar 5 (c)). Lapisan tersebut yang menyebabkan nilai laju alir menurun. Penebalan lapisan bertambah seiring pertambahan durasi anodizing sehingga mengakibatkan penurunan nilai laju alir [5]. Lapisan terbentuk karena kandungan $\mathrm{Al}_{2} \mathrm{O}_{3}$ yang relatif tinggi pada lempung.

Tabel 4. Laju alir keramik setelah anodizing

\begin{tabular}{cccccc}
\hline Sampel & \multicolumn{3}{c}{ Volume (mL) untuk lama waktu } & Jumlah Laju Alir \\
\cline { 2 - 4 } & 24 & $\begin{array}{c}48 \\
\text { (jam) }\end{array}$ & $\begin{array}{c}72 \\
\text { (jam) }\end{array}$ & $\begin{array}{c}96 \\
\text { (jam) }\end{array}$ & \\
\hline 1 & 0 & 0,35 & 1,21 & 1,41 & 0,0309 \\
2 & 0 & 0,34 & 1,2 & 1,42 & 0.0308 \\
3 & 0 & 0,32 & 1,21 & 1,42 & 0.0307 \\
4 & 0 & 0,32 & 1,21 & 1,42 & 0.0304 \\
5 & 0 & 0,3 & 1,2 & 1,4 & 0.0302 \\
\hline
\end{tabular}




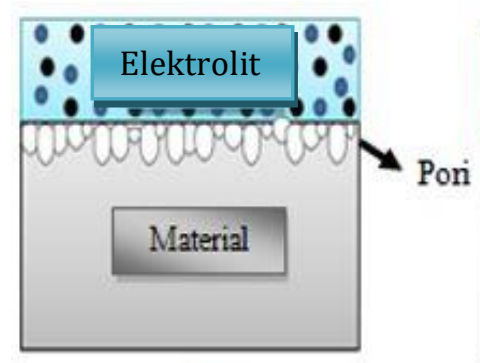

a

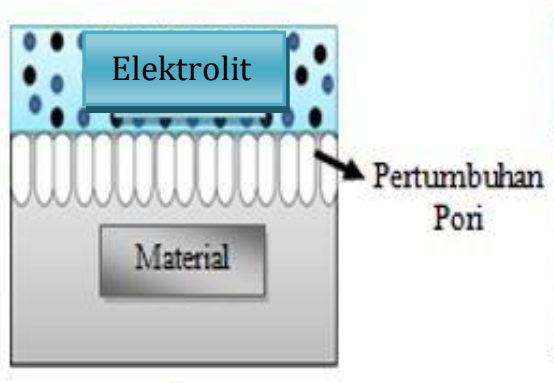

b

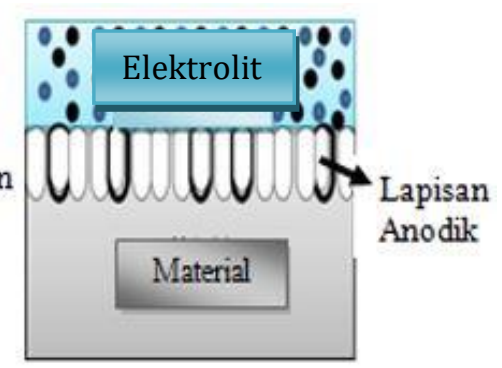

c

Gambar 5 Ilustrasi proses pembentukan pori pada sampel: (a) Ketidakteraturan pori sebelum dilakukan anodizing, (b) Pori mulai terbentuk dan teratur setelah dilakukan anodizing, (c) Terdapat lapisan penghalang (lapisan anodik) setelah anodizing

\section{Kesimpulan}

Berdasarkan penelitian yang telah dilakukan, dapat disimpulkan bahwa penerapan teknik anodizing menghasilkan peningkatan porositas keramik berbahan baku lempung. Nilai porositas semakin meningkat seiring pertambahan waktu anodizing. Porositas tertinggi diperoleh oleh sampel dengan waktu anodizing 30 menit sebesar 49,34\%. Nilai laju alir seiring pertambahan lama waktu anodizing mengalami penurunan.

\section{Ucapan Terima Kasih}

Penulis mengucapkan terimakasih kepada COMDEV \& OUTREACHING UNTAN yang telah mendanai riset.

\section{Daftar Pustaka}

[1] Nugrahaningtyas, D.K., Widjonarko, D.M., Daryani, Haryanti, Y., 2016. Kajian Aktivitasi $\mathrm{H}_{2} \mathrm{SO}_{4} \quad$ Terhadap Proses Pemilaran $\mathrm{Al}_{2} \mathrm{O}_{3}$ Pada Lempung Alam Pacitan. Jurnal Penelitian Kimia, Alchemy. 12(2). 190-203. 2016.

[2] Ridayani, D., Malino, M.B., Asri., Analisis Porositas dan Susut Bakar Keramik Berposi Berbasis Clay dan Serat Tandan Kosong Kelapa Sawit. Jurnal Prisma Fisika 8(2). 51-54. 2016.

[3] Chu, SZ., Wada., Inoue, S., Isogani, M., Katsuta., Yasumori A., Large-Scale Fabrication of Ordered Nanoporous Alumina Films with Arbitrary Pore Intervals by Cricital-Potential Anodization Journal of The Electrochemical Society. Society. 153(9), B384-B391, 2006.

[4] Qodari, M. T., Karakterisasi Lempung dari Daerah Pagedengan Kec Turun Kab Malang. Skripsi, Jurusan Kimia Fakultas Sains dan Teknologi UINM. 2010.
[5] Li, Y., Ling, ZY., Chen, SS., Wang, JC., Fabrication of Novel Porous Anodic Alumina Membrans by Two-Step Hard Anodization. Departemen Elektronik Material Science and Rekayasa, South China University of Technology, $381 \mathrm{Wu}$ Shan Road, Guanngzhou 510.640, Republik Rekayasa Cina, Journal Nanotechnology. 19. 1-6. 2008.

[6] Nugroho, F., Pengaruh Rapat Arus Anodization Terhadap Nilai Kekerasan Pada Plat Aluminium Paduan AA Seri 2024-T3. Jurnal Angkasa, Teknik Mesin, Sekolah Tinggi Teknologi Adisutjipto, Yogyakarta. 7(2). 39-47. 2015

[7] Simanjuntak, R,. Pembuatan dan Karakterisasi Keramik Konstruksi dengan Memanfaatkan Limbah Padat Pulp dengan Bahan Baku Kaolin Surabaya. Skripsi Fisika FMIPA USU. 2010. 